(2) Open Access Full Text Article

\title{
Does whey protein supplementation affect blood pressure in hypoalbuminemic peritoneal dialysis patients?
}

\author{
Kamal Hassan ${ }^{1,2}$ \\ Fadi Hassan ${ }^{3}$ \\ 'Faculty of Medicine in the Galilee, \\ Bar-Ilan University, Safed, ${ }^{2}$ Department \\ of Nephrology and Hypertension, \\ Peritoneal Dialysis Unit, ${ }^{3}$ Department \\ of Internal Medicine E, Galilee Medical \\ Center, Nahariya, Israel
}

This article was published in the following Dove Press journal:

Therapeutics and Clinical Risk Management

14 August 2017

Number of times this article has been viewed

Objective: Hypertension and hypoalbuminemia are common risk factors for cardiovascular complications in peritoneal dialysis (PD) patients. Data are limited regarding the effects of whey protein consumption on blood pressure in this population. The aim of the present study was to examine if whey protein supplementation for 12 weeks to hypoalbuminemic PD patients affects their blood pressure.

Patients and methods: This prospective randomized study included 36 stable PD patients with serum albumin levels $<3.8 \mathrm{~g} / \mathrm{dL}$. During 12 weeks, 18 patients were instructed to consume $1.2 \mathrm{~g} / \mathrm{kg}$ /day of protein and an additional whey protein supplement at a dose of $25 \%$ of the instructed daily protein (whey protein group). Eighteen patients were instructed to consume protein in the amount of $1.2 \mathrm{~g} / \mathrm{kg} /$ day and an additional $25 \%$, without whey protein supplementation (control group).

Results: Compared to the control group, in the whey protein group, serum albumin levels, oncotic pressure, and dialysate ultrafiltration significantly increased $(3.55 \pm 0.14$ to $4.08 \pm 0.15 \mathrm{~g} / \mathrm{dL}, P<0.001 ; 21.81 \pm 2.03$ to $24.06 \pm 1.54 \mathrm{mmHg}, P<0.001 ; 927.8 \pm 120.3$ to $1,125.0 \pm 125.1 \mathrm{~mL} /$ day, $P<0.001$; respectively) and were significantly higher after 12 weeks (4.08 \pm 0.15 vs $3.41 \pm 0.49 \mathrm{~g} / \mathrm{dL}, P<0.001 ; 24.06 \pm 1.54$ vs $22.71 \pm 1.77 \mathrm{mmHg}, P=0.010$; $1,125.0 \pm 125.1$ vs $930.6 \pm 352.8 \mathrm{~mL} /$ day, $P=0.017$; respectively) in the whey protein group compared to the control group. Fluid overload, the extracellular to intracellular ratio and mean arterial pressure (MAP) significantly decreased $(2.46 \pm 1.08$ to $1.52 \pm 0.33, P<0.001 ; 1.080 \pm 0.142$ to $0.954 \pm 0.124, P<0.001 ; 102.6 \pm 3.80$ to $99.83 \pm 3.85, P=0.018$; respectively) and were significantly lower in the whey protein group after 12 weeks $(1.52 \pm 0.33$ vs $2.23 \pm 0.73, P<0.001$, $0.954 \pm 0.124$ vs $1.048 \pm 0.111, P=0.002 ; 99.83 \pm 3.85$ vs $102.8 \pm 3.93, P=0.018$; respectively).

Conclusion: Whey protein supplementation for 12 weeks decreased MAP in hypoalbuminemic PD patients.

Keywords: blood pressure, hydration status, oncotic pressure, peritoneal dialysis, whey protein

\section{Introduction}

Hypertension and hypoalbuminemia (serum albumin levels below $3.8 \mathrm{~g} / \mathrm{dL}$ ) are well-known independent and common risk factors for cardiovascular complications in peritoneal dialysis (PD) patients and considered a major cause for morbidity and mortality in this population. ${ }^{1-4}$

The relationship between blood pressure and serum albumin levels remains unclear among hypoalbuminemic PD patients. A positive association between blood pressure and serum albumin levels was reported..$^{5-7}$ Lower blood pressure was also reported
Correspondence: Kamal Hassan Department of Nephrology and Hypertension, Peritoneal Dialysis Unit, Galilee Medical Center - Nahariya, POB 2I, Nahariya 22100, Israel Tel +972 57887913

Fax +97249107482

Email kamalh@gmc.gov.il 
in hypoalbuminemic patients with proteinuria compared to those with normal serum albumin. ${ }^{8}$

Based on the National Kidney Foundation Kidney Disease Outcomes Quality Initiative (NKF-KDOQI) and European Best Practice Guidelines (EBPG), the recommended daily protein intake in PD should be $1.2-1.3 \mathrm{~g} / \mathrm{kg} / \mathrm{day}$, to maintain serum albumin levels above $4.0 \mathrm{~g} / \mathrm{dL}$. However, a number of reports have shown that daily protein intake in this population is actually $<0.9-1.1 \mathrm{~g} / \mathrm{kg} /$ day. ${ }^{9-11}$ Factors affecting the development of hypoalbuminemia in PD patients include malnutrition, peritoneal protein loss, lack of appetite resulting from abdominal fullness or related to the absorption of glucose from the dialysate, slow emptying of the stomach, and chronic inflammation. ${ }^{12}$

Although dietary supplements are frequently recommended for hypoalbuminemic dialysis patients, oral protein supplements are usually not tolerated, and distressing side effects have been shown to result in a high degree of noncompliance. ${ }^{13,14}$ Whey protein, which is a major component of bovine milk, is marketed as a food supplement. Whey protein is highly digestible and is absorbed rapidly. ${ }^{15-17}$ It contains all the essential amino acids and bioactive peptides that mediate physiological processes such as lowering plasma cholesterol levels, antithrombotic activity, antibacterial and antiviral activities, and enhancing physiologic and anabolic stimulus to protein synthesis and muscle building and has also been reported to exert positive effects on carbohydrate metabolism. ${ }^{18-27}$ Moreover, epidemiologic studies suggest associations of the consumption of milk and dairy products with a lower risk of metabolic and cardiovascular disorders due to bioactive components such as lactoferrin and glutamine. ${ }^{25,26}$ Side effects of whey protein usually consist of gastrointestinal complaints such as abdominal pain and swellings and are probably due to lactose intolerance. ${ }^{28}$

Components of whey protein have been shown to mediate antihypertensive effects ${ }^{29}$ and to inhibit the angiotensinconverting enzyme (ACE). ${ }^{30-33}$ Despite the wide use of various protein supplements in the general population and among dialysis patients, the effects of whey protein supplementation on blood pressure in PD patients remain to be determined. Thus, the aim of the present study was to examine if whey protein supplementation for 12 weeks to hypoalbuminemic PD patients affects their blood pressure.

\section{Patients and methods Study population}

This prospective randomized pilot study included 36 stable patients on maintenance PD for a period of $>12$ months and with serum albumin levels $<3.8 \mathrm{~g} / \mathrm{dL}$. The Medical Ethics
Committee of Galilee Medical Center, Nahariya, Israel approved the study protocol (Number: NHR-0019-15). All participants signed written informed consent for this study. Hospitalization, any evidence of infection including peritonitis, cardiovascular, and neurological events in the last 6 months prior to enrolment, as well as liver disorders, malignancies, and gastrointestinal diseases were considered exclusion criteria. Participants were randomized by computer to two groups, which were similar in their demographic, nutritional, and PD characteristics. Eighteen patients were instructed to consume $1.2 \mathrm{~g} / \mathrm{kg} /$ day of protein and an additional whey protein supplement at a dose of $25 \%$ of the instructed daily protein (whey protein group). Eighteen patients were instructed to consume protein in the amount of $1.2 \mathrm{~g} / \mathrm{kg} /$ day and an additional $25 \%$, without whey protein supplementation (control group). An experienced dietitian counseled the patients in both groups regarding adjusting their daily protein intake and counseled the participants in the whey protein group regarding their whey protein dosage. Each participant in the whey protein group was given the opportunity to choose one of five flavors of the whey protein supplement: coffee, chocolate, banana, vanilla, or neutral (flavor free).

Whey protein powder supplement was consumed in two doses mixed with breakfast and evening meals. Participants were asked to record their consumption of daily protein intake. Patients in the whey protein group were also asked to record their consumption of whey protein as well as to keep empty sachets to monitor compliance. All participants in the whey protein group received the same whey protein supplied by the PD unit staff. The patients included in this group received a detailed explanation from the medical staff regarding possible side effects. The composition of the whey protein supplement is shown in Table 1. All participants continued their PD prescription and antihypertensive therapy and

Table I Nutritional information of the whey protein supplement (powder) used in this study, per $100 \mathrm{~g}$ and per the quantity in a measuring spoon

\begin{tabular}{lll}
\hline Nutrition information & $\begin{array}{l}\text { Whey protein } \\
\text { powder 100 g }\end{array}$ & $\begin{array}{l}\text { Measuring } \\
\text { spoon 13.3 g }\end{array}$ \\
\hline Energy (calories) & 393 & 52 \\
Whey protein $(\mathrm{g})$ & 75.0 & 10 \\
Carbohydrate $(\mathrm{g})$ & 14.6 & 2.0 \\
Fat $(\mathrm{g})$ & 4.5 & 0.6 \\
Saturated fatty acids $(\mathrm{g})$ & 2.7 & 0.4 \\
Trans fatty acids $(\mathrm{g})$ & $<0.5$ & $<0.5$ \\
Cholesterol (mg) & 188 & 25 \\
Phosphorus (mg) & 349 & 46 \\
Potassium (mg) & 735 & 98 \\
Sodium (mg) & 255 & 34 \\
\hline
\end{tabular}


remained under strict dietary and nephrological follow-up to assess compliance and clinical status during the 12-week study period. Serum albumin levels, oncotic pressure, hydration status, mean arterial pressure (MAP), nutritional status, and plasma high-sensitivity C-reactive protein (hsCRP) levels were evaluated at the initiation of the study and after 12 weeks.

\section{Determination of serum albumin levels}

Serum albumin levels were determined by BCG according to the Aeroset chemical analyzer instructions (Abbott Laboratories, Abbott Park, IL, USA). The limit of detection for this assay is $0.3 \mathrm{~g} / \mathrm{dL}$.

\section{Measurement of oncotic pressure}

Oncotic pressure was measured in sera using a colloid osmometer (Wescor, Logan, UT, USA), which operates using a membrane with a cutoff of $30 \mathrm{kDa}$. Thus, the measured oncotic pressure relates only to proteins with a molecular mass $>30 \mathrm{kDa}$.

\section{Assessment of hydration status}

Hydration status was assessed by a whole-body bioimpedance spectroscopy technique using the Fresenius Medical Care Body Composition Monitor (BCM) device, Bad Homburg, Germany. ${ }^{34}$ This method is considered to be a practical, safe, simple, reliable, accurate, and noninvasive technique for the assessment of fluid overload (FO). Regarding the differences in body size, the extracellular to intracellular water ratio (E/I ratio) was used as an independent and comparable indicator of hydration status.

\section{Blood pressure measurement}

MAP was evaluated using the Mobil-O-Graph device for 24-h ambulatory blood pressure monitoring (Industrielle Entwicklung Medizintechnik GmbH, D-52222 Stolberg, Germany).

\section{Assessment of nutritional status}

Normalized protein equivalent of total nitrogen appearance (nPNA) was used to assess the nutritional status of all participants. nPNA was calculated by the Bergstrom formula (2): $:^{35}$

$$
\begin{aligned}
& \text { PNA (g/day) } \\
& \quad=15.1+6.95 \text { UNA (g/day) } \\
& + \text { Dialysate protein losses (g/day) }
\end{aligned}
$$

PNA (g/day)

$$
=\text { Protein equivalent of total nitrogen appearance }
$$

$$
\begin{aligned}
& \text { nPNA (g/kg/day) } \\
& =\text { Normalization of PNA to "dry" body weight } \\
& \text { "Dry" body weight }(\mathrm{kg}) \\
& \quad=\text { Actual body weight - Fluid overload }
\end{aligned}
$$

(fluid overload and "dry" body weight were obtained by the assessment of hydration status using the BCM device)

$$
\begin{aligned}
\operatorname{UNA}(\mathrm{g} / \text { day })= & \text { Urea nitrogen appearance } \\
= & \text { Urinary urea losses }(\mathrm{g} / \text { day }) \\
& + \text { Dialysate urea losses }(\mathrm{g} / \text { day })
\end{aligned}
$$

For the calculation of urinary urea losses and dialysate urea losses, 24-h collections of urine and dialysate were performed.

\section{Statistical methods}

Statistical Package for the Social Sciences (SPSS) version 21 (IBM Corporation, Armonk, NY, USA) software was used to perform the statistical analysis. Continuous variables are reported as means and standard deviations and categorical variables as percentages and frequencies. Continuous variables in the study groups were compared using the unpaired $t$-test. These variables included age, residual renal function (RRF), PD vintage, blood urea nitrogen (BUN), serum creatinine, urine output, $\mathrm{Kt} / \mathrm{v}$ (a dimensionless index that measures the fractional urea clearance during dialysis: $\mathrm{K}=$ blood urea clearance $[\mathrm{L} / \mathrm{h}], \mathrm{t}=$ dialysis length $[\mathrm{h}]$, $\mathrm{V}=$ distribution volume of urea [L]), nPNA, hsCRP, serum calcium and phosphorus, hemoglobin, $\mathrm{HbA} 1 \mathrm{c}, \mathrm{BMI}$, serum albumin, oncotic pressure, dialysate ultrafiltration, FO, the $\mathrm{E} / \mathrm{I}$ ratio, and MAP. Categorical variables in the study groups were compared using Fisher's exact test. Such variables included gender, the presence of diabetes, PD modality, peritoneal membrane characteristics, primary renal diseases, and antihypertensive therapy. $P<0.05$ was considered to be significant.

\section{Results}

Age, gender, the presence of diabetes, serum albumin, HbA1c, BMI, RRF, daily urine output, daily dialysate ultrafiltration, $\mathrm{PD}$ modality, $\mathrm{PD}$ vintage, $\mathrm{Kt} / \mathrm{v}$, peritoneal membrane characteristics, primary renal disease, and antihypertensive medications were comparable between the study groups (Table 2). All participants completed the 12-week study period, without hospitalization and without developing infections (including peritonitis), cardiovascular complications, neurological events, or liver function abnormalities. 
Table 2 Demographic and clinical characteristics of the study population

\begin{tabular}{|c|c|c|c|}
\hline Variables & $\begin{array}{l}\text { Whey protein group } \\
(n=18)\end{array}$ & $\begin{array}{l}\text { Control group } \\
(n=18)\end{array}$ & $P$-value \\
\hline Age (years) & $59.7 \pm 11.5$ & $58.1 \pm 12.3$ & 0.338 \\
\hline Males/females, n (\%)/n (\%) & $9(47.4) / 10(52.6)$ & $7(4 \mid .2) / 10$ (58.8) & 0.485 \\
\hline Diabetes mellitus, n (\%) & $9(47.4)$ & $8(47.1)$ & 0.624 \\
\hline $\operatorname{RRF}\left(\mathrm{mL} / \mathrm{min} / \mathrm{l} .73 \mathrm{~m}^{2}\right)$ & $5.7 \pm 2.0$ & $6.1 \pm 2.1$ & 0.254 \\
\hline CAPD/APD, n (\%)/n (\%) & $12(63.2) / 7(36.8)$ & II (64.7)/6 (35.3) & 0.366 \\
\hline PD vintage & $26.3 \pm 15.2$ & $24.9 \pm 10.8$ & 0.379 \\
\hline HAT/LAT & $10(52.6) / 9(47.4)$ & $9(52.9) / 8(47.1)$ & 0.623 \\
\hline \multicolumn{4}{|l|}{ Primary renal disease } \\
\hline Diabetes mellitus, n (\%) & $8(44.4)$ & $8(44.4)$ & 1.000 \\
\hline Hypertension, n (\%) & $7(33.3)$ & $5(27.8)$ & 0.725 \\
\hline APKD, n (\%) & I (5.6) & I (5.6) & 1.000 \\
\hline Unkown, n (\%) & $3(16.7)$ & $4(22.2)$ & 1.000 \\
\hline \multicolumn{4}{|l|}{ Antihypertensive therapy } \\
\hline Loop diuretics & $14(83.3)$ & $16(88.9)$ & 0.658 \\
\hline ACEI/ARB & $3(27.8)$ & $5(27.8)$ & 0.691 \\
\hline Calcium channel blockers & $15(83.3)$ & $12(66.7)$ & 0.443 \\
\hline Beta blockers & $5(33.3)$ & $7(38.9)$ & 0.725 \\
\hline Alpha blockers & $3(15.8)$ & $3(17.6)$ & 0.614 \\
\hline
\end{tabular}

Note: Values of age, BMI, PD vintage, RRF, and $\mathrm{Kt} / \mathrm{V}$ are presented as means and standard deviations

Abbreviations: RRF, residual renal function; CAPD, continuous ambulatory peritoneal dialysis; APD, automated peritoneal dialysis; PD, peritoneal dialysis; Kt/ $\mathrm{V}$ (a dimensionless index that measures the fractional urea clearance during dialysis: $\mathrm{K}=$ blood urea clearance $[\mathrm{L} / \mathrm{h}], \mathrm{t}=\mathrm{dialysis}$ length $[\mathrm{h}], \mathrm{V}=\mathrm{distribution}$ volume of urea $[\mathrm{L}]$ ); HAT, high average transporters; LAT, low average transporters; APKD, adult polycystic kidney disease; ACEl, angiotensin-converting enzyme inhibitors; ARB, angiotensin receptor inhibitors.

The mean daily dose of whey powder used in the whey protein group was $26.3 \pm 3.1 \mathrm{~g} /$ day.

Compared to the control group, in the whey protein group, serum albumin levels, oncotic pressure, and dialysate ultrafiltration significantly increased $(3.55 \pm 0.14$ to $4.08 \pm 0.15 \mathrm{~g} / \mathrm{dL}$, $P<0.001 ; 21.81 \pm 2.03$ to $24.06 \pm 1.54 \mathrm{mmHg}, P<0.001$; $927.8 \pm 120.3$ to $1,125.0 \pm 125.1 \mathrm{~mL} /$ day, $P<0.001$; respectively) and were significantly higher after 12 weeks $(4.08 \pm 0.15$ vs $3.41 \pm 0.49 \mathrm{~g} / \mathrm{dL}, P<0.001 ; 24.06 \pm 1.54$ vs $22.71 \pm 1.77 \mathrm{mmHg}$, $P=0.010 ; 1,125.0 \pm 125.1$ vs $930.6 \pm 352.8 \mathrm{~mL} /$ day, $P=0.017$; respectively) in the whey protein group compared to the control group (Figure $1 \mathrm{~A}-\mathrm{C}$ ).

FO, E/I ratio, and MAP significantly decreased $(2.46 \pm 1.08$ to $1.52 \pm 0.33, P<0.001 ; 1.080 \pm 0.142$ to $0.954 \pm 0.124$, $P<0.001 ; 102.6 \pm 3.80$ to $99.83 \pm 3.85, P=0.018$; respectively) and were significantly lower in the whey protein group after 12 weeks $(1.52 \pm 0.33$ vs $2.23 \pm 0.73, P<0.001,0.954 \pm 0.124$ vs $1.048 \pm 0.111, P=0.002 ; 99.83 \pm 3.85$ vs $102.8 \pm 3.93, P=0.018$; respectively) (Figure 1D-F).

All participants had nPNA levels below the recommended target of $1.2 \mathrm{~g} / \mathrm{kg} /$ day and elevated plasma hsCRP levels $(>5 \mathrm{mg} / \mathrm{dL})$ at the initiation of the study. Compared to the control group, in the whey protein group, nPNA, BUN, serum calcium, phosphorus, and hemoglobin levels significantly increased $(0.968 \pm 0.073$ to $1.113 \pm 0.085$, $P<0.001 ; 60.64 \pm 10.38$ to $67.56 \pm 8.22, P=0.017 ; 8.97 \pm 0.39$ to $9.44 \pm 0.21, P<0.001 ; 5.22 \pm 0.56$ to $6.12 \pm 0.83, P<0.001$ $10.97 \pm 1.97$ to $11.63 \pm 0.92, P=0.033$; respectively) and were higher in the whey protein group after 12 weeks $(1.113 \pm 0.085$ vs $1.031 \pm 0.083, P=0.003 ; 67.56 \pm 8.22$ vs $59.88 \pm 17.12$, $P=0.047 ; 9.44 \pm 0.21$ vs $9.03 \pm 0.41, P<0.001 ; 6.12 \pm 0.83$ vs $5.33 \pm 0.76, P=0.003 ; 11.63 \pm 0.92$ vs $10.32 \pm 1.03, P<0.001$; respectively) (Table 3 ).

In the whey protein group, plasma hsCRP levels significantly decreased $(12.53 \pm 2.70$ to $10.19 \pm 2.17, P=0.007)$ and were lower than in the control group after 12 weeks (10.19 \pm 2.17 vs $13.16 \pm 1.70, P<0.001)$ (Table 3).

Serum creatinine, urine output, Kt/V, HbAlc, and BMI did not change significantly in either group (Table 3 ).

In the whey protein group, $16.7 \%(3 / 18)$ reported a feeling of satiety and $11.1 \%(2 / 18)$ reported bloating. Decreasing the whey protein intake to $50 \%$ of the instructed dose led to prompt relief of complaints. In the control group, 5.6\% $(1 / 18)$ complained of flatulence.

\section{Discussion}

The main findings of the present study were the significant increase in serum albumin levels, oncotic pressure, and dialysate ultrafiltration, leading to significant improvement in hydration status and significant reduction in MAP in PD patients who received whey protein supplementation during a 12-week period, compared to a control group (Figure 1). 


\section{A}

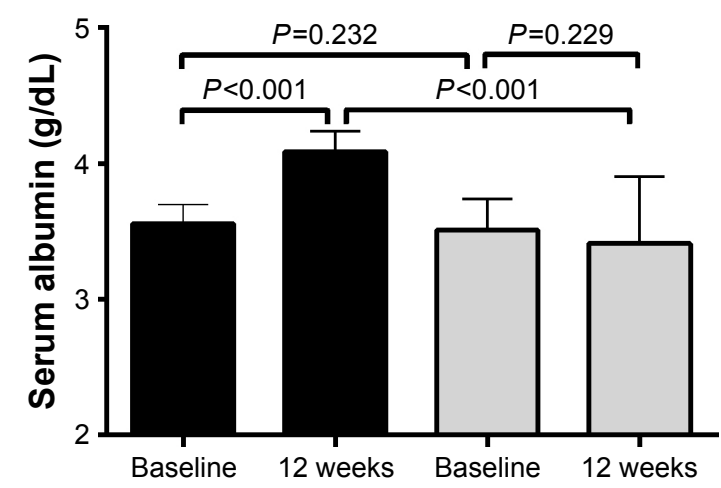

C

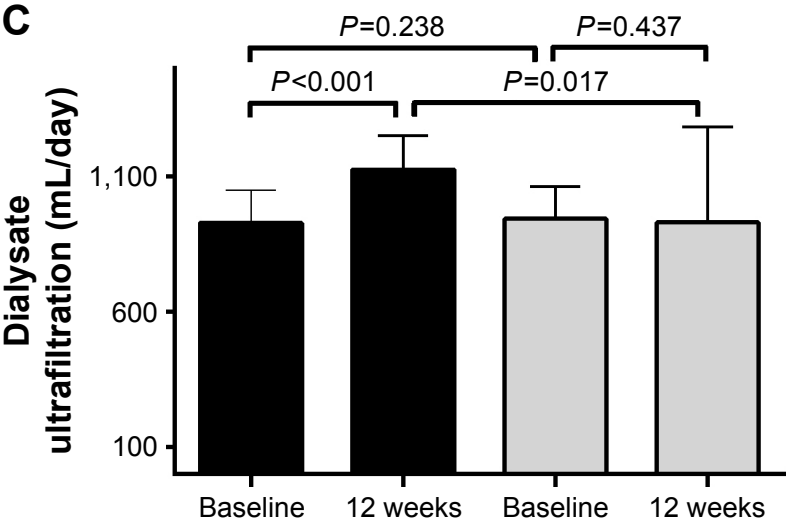

E

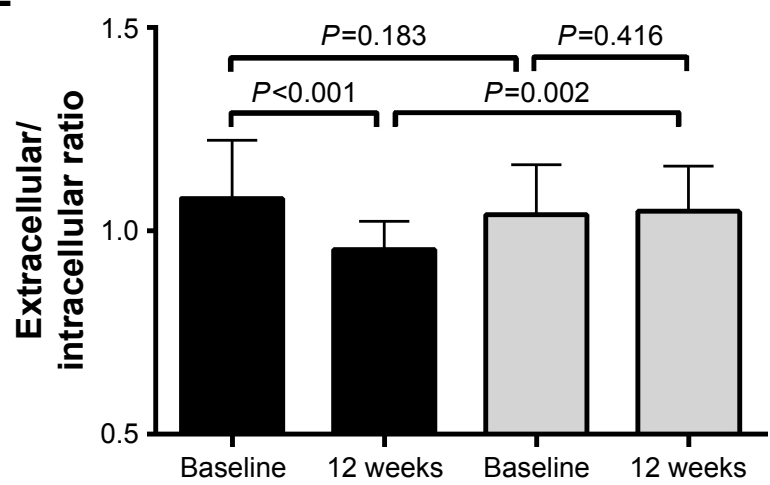

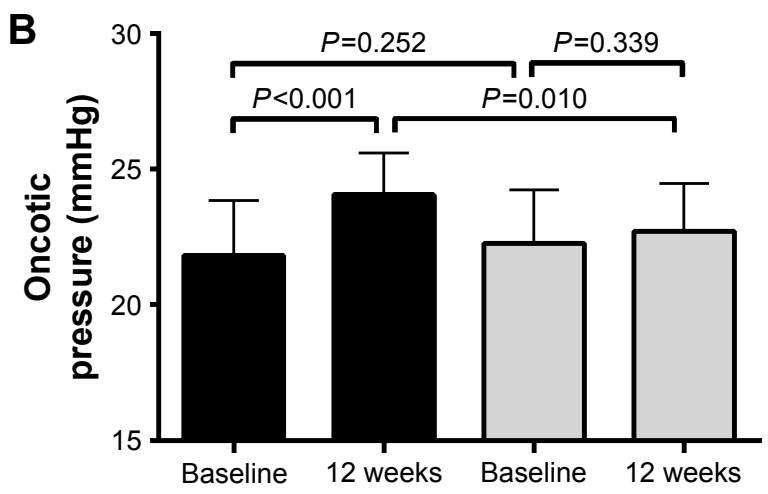

D

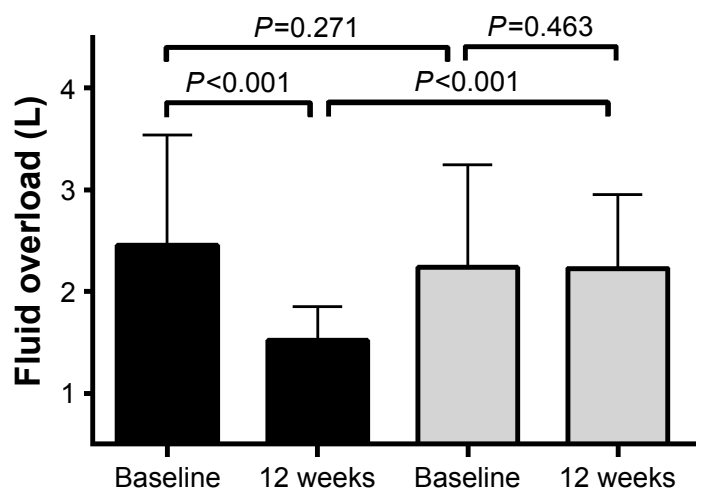

$\mathbf{F}$

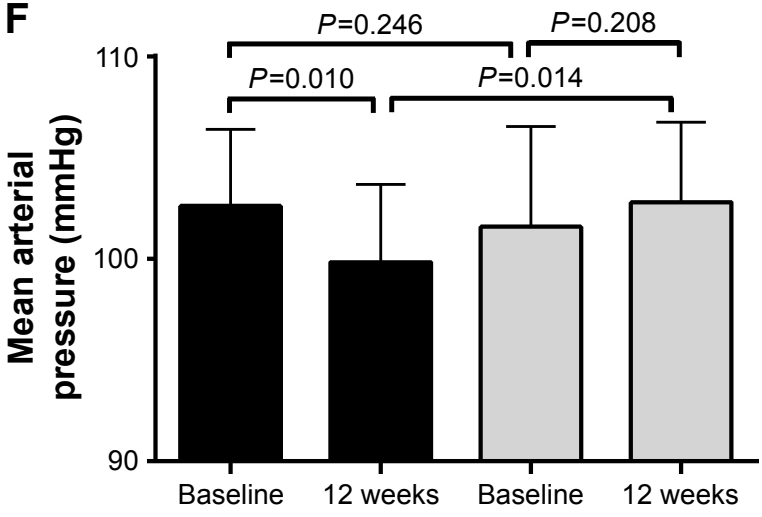

Whey protein group

Control group

Figure I The effects in hypoalbuminemic peritoneal dialysis patients of 12 weeks of whey protein supplementation on serum albumin levels (A), oncotic pressure (B), dialysate ultrafiltration (C), fluid overload (D), the extracellular/intracellular water ratio (E), and mean arterial pressure (F) compared to a control group.

Small reductions in blood pressure of $2-5 \mathrm{mmHg}$ may reduce mortality due to stroke and coronary heart disease. ${ }^{36}$ Epidemiological and clinical studies have shown an inverse relationship between the incidence of stroke and the consumption of milk and milk products. . $02,26,27,37,38$ Generally, two distinct mechanisms may affect blood pressure in hypoalbuminemic patients. ${ }^{26,37,38}$ First, in those with normal renal function and normal renal excretion of sodium and water, low serum albumin decreases oncotic pressure, reduces blood volume, and stimulates the rennin-angiotensin-aldosterone system; this results in renal sodium and water retention and vasoconstriction. The second mechanism is relevant to hypoalbuminemic PD patients with extremely low RRF. In this population, impaired renal sodium and water excretion leads to the development of overhydration and hypertension.

Although a rise in serum albumin levels and oncotic pressure may be accompanied by an elevation in blood pressure, in this study, blood pressure decreased significantly among hypoalbuminemic PD patients who received whey protein. 
Table 3 Comparisons between clinical variables of the whey protein and control groups at baseline (0) and after 12 weeks (I2)

\begin{tabular}{|c|c|c|c|}
\hline Variables & $\begin{array}{l}\text { Whey protein group } \\
(n=18)\end{array}$ & $\begin{array}{l}\text { Control group } \\
(n=18)\end{array}$ & $P$-value \\
\hline $\mathrm{BUN}_{0}(\mathrm{mg} / \mathrm{dL})$ & $60.64 \pm 10.38$ & $59.03 \pm 10.70$ & 0.324 \\
\hline \multirow[t]{2}{*}{$\mathrm{BUN}_{12}(\mathrm{mg} / \mathrm{dL})$} & $67.56 \pm 8.22$ & $59.88 \pm 17.12$ & 0.047 \\
\hline & 0.017 & 0.429 & \\
\hline Serum creatinine $_{0}(\mathrm{mg} / \mathrm{dL})$ & $10.78 \pm 3.07$ & $10.72 \pm 2.55$ & 0.477 \\
\hline \multirow[t]{2}{*}{ Serum creatinine $_{12}(\mathrm{mg} / \mathrm{dL})$} & $10.01 \pm 3.80$ & $11.06 \pm 2.53$ & 0.169 \\
\hline & 0.254 & 0.349 & \\
\hline Urine output $_{0}(\mathrm{~mL} /$ day $)$ & $\mathrm{I}, 097 \pm 622.3$ & $\mathrm{I}, 078 \pm 749.7$ & 0.467 \\
\hline \multirow[t]{2}{*}{ Urine output $_{12}(\mathrm{~mL} /$ day $)$} & $I, \mid 142 \pm 643.1$ & $894.4 \pm 567.5$ & 0.339 \\
\hline & 0.417 & 0.220 & \\
\hline $\mathrm{Kt} / \mathrm{V}_{0}$ & $1.83 \pm 0.39$ & $1.89 \pm 0.16$ & 0.300 \\
\hline \multirow[t]{2}{*}{$\mathrm{Kt} / \mathrm{V}_{12}$} & $1.95 \pm 0.54$ & $1.92 \pm 0.19$ & 0.419 \\
\hline & 0.232 & 0.271 & \\
\hline nPNA (g/kc/day) $)_{0}$ & $0.968 \pm 0.073$ & $0.999 \pm 0.099$ & 0.145 \\
\hline \multirow[t]{2}{*}{ nPNA $(\mathrm{g} / \mathrm{kc} / \text { day })_{12}$} & $1.113 \pm 0.085$ & $1.031 \pm 0.083$ & 0.003 \\
\hline & $<0.001$ & 0.149 & \\
\hline hsCRP (mg/dL) & $12.53 \pm 2.70$ & $12.96 \pm 2.76$ & 0.321 \\
\hline \multirow[t]{2}{*}{$\mathrm{hsCRP}(\mathrm{mg} / \mathrm{dL})$} & $10.19 \pm 2.17$ & $13.16 \pm 1.70$ & $<0.00 \mathrm{I}$ \\
\hline & 0.007 & 0.395 & \\
\hline Serum calcium $0(\mathrm{mg} / \mathrm{dL})$ & $8.97 \pm 0.39$ & $9.08 \pm 0.35$ & 0.188 \\
\hline \multirow[t]{2}{*}{ Serum calcium $_{12}(\mathrm{mg} / \mathrm{dL})$} & $9.44 \pm 0.21$ & $9.03 \pm 0.4 \mathrm{I}$ & $<0.00 \mathrm{I}$ \\
\hline & $<0.001$ & 0.332 & \\
\hline Serum phosphorus ${ }_{0}(\mathrm{mg} / \mathrm{dL})$ & $5.22 \pm 0.56$ & $5.26 \pm 0.62$ & 0.422 \\
\hline \multirow[t]{2}{*}{ Serum phosphorus $12(\mathrm{mg} / \mathrm{dL})$} & $6.12 \pm 0.83$ & $5.33 \pm 0.76$ & 0.003 \\
\hline & $<0.001$ & 0.378 & \\
\hline Hemoglobin $_{0}(\mathrm{~g} / \mathrm{dL})$ & $10.97 \pm 1.17$ & $10.61 \pm 1.07$ & 0.170 \\
\hline \multirow[t]{2}{*}{ Hemoglobin $_{12}(\mathrm{~g} / \mathrm{dL})$} & $11.63 \pm 0.92$ & $10.32 \pm 1.03$ & $<0.00$ I \\
\hline & 0.033 & & \\
\hline $\mathrm{HbAIc}(\%)$ & $7.47 \pm 0.54$ & $7.37 \pm 0.4 \mathrm{I}$ & 0.267 \\
\hline \multirow[t]{2}{*}{$\mathrm{HbAlc}_{12}(\%)$} & $7.45 \pm 0.32$ & $7.29 \pm 0.45$ & 0.121 \\
\hline & 0.455 & 0.309 & \\
\hline $\mathrm{BMI}_{0}\left(\mathrm{~kg} / \mathrm{m}^{2}\right)$ & $28.7 I \pm 3.32$ & $28.66 \pm 3.56$ & 0.483 \\
\hline \multirow[t]{2}{*}{$\mathrm{BMI}_{12}\left(\mathrm{~kg} / \mathrm{m}^{2}\right)$} & $28.79 \pm 3.38$ & $28.53 \pm 3.99$ & 0.415 \\
\hline & 0.420 & 0.458 & \\
\hline
\end{tabular}

Note: Values of all variables are presented as means and standard deviations.

Abbreviations: BUN, blood urea nitrogen; $\mathrm{Kt} / \mathrm{V}$ (a dimensionless index that measures the fractional urea clearance during dialysis: $\mathrm{K}=$ blood urea clearance [L/h], $\mathrm{t}=$ dialysis length $[\mathrm{h}], \mathrm{V}=$ distribution volume of urea $[\mathrm{L}]$ ); nPNA, normalized protein equivalent of total nitrogen appearance; hsCRP, high sensitivity $\mathrm{C}$-reactive protein.

Two mechanisms may be involved in the reduction in blood pressure in this population. First, the significant increase in serum albumin levels and oncotic pressure in the whey protein group enhances movement of excess extracellular fluid, as is reflected by the significant reduction in the E/I ratio, into the intravascular compartment. This leads to better peritoneal clearance of excess fluid and lowering of the FO and blood pressure. Second, the renin-angiotensin system is well recognized for its role as a regulator of blood pressure. Previous studies showed that milk proteins can inhibit ACE activity. ${ }^{31-34,39-41}$ Numerous whey protein-derived peptides, known as lactokinins, acting as ACE inhibitors, have been identified. ${ }^{31-34,42}$ Clinical trials in hypertensive animals and humans showed that whey protein-derived lactokinins can induce a significant reduction in blood pressure. ${ }^{31,33,34,43}$
Our findings in hypoalbuminemic PD patients concur with several studies that demonstrated a blood pressure lowering effect of whey protein in other human populations. ${ }^{33,37,40-42,44,45}$ Among overweight-obese individuals, whey protein supplementation for 12 weeks showed a significant decrease in systolic and diastolic blood pressure. ${ }^{37}$ Moreover, normal daily use for 21 weeks of fermented milk containing bioactive peptides was shown to have a blood pressure-lowering effect in hypertensive subjects. ${ }^{40}$ The intake of fermented milk enriched with whey proteins was shown to lower blood pressure after 8 weeks in healthy men. ${ }^{41}$ However, another study found that daily consumption of $125 \mathrm{~mL}$ of a milk drink, supplemented with whey peptides (2.6 g), did not reduce blood pressure in mildly hypertensive subjects. ${ }^{38}$ The authors of that study suggested that a higher dose of whey 
proteins may be required to exert a measurable biological effect in humans. The physiologic effects of whey protein may be mediated by certain whey protein-derived peptides or amino acids or by synergistic actions between them.

The usual dietary phosphorus intake in nonuremic individuals is $1.0-1.8 \mathrm{~g} /$ day. In dialysis patients, phosphorus intake should be restricted to $0.6-1.2 \mathrm{~g} / \mathrm{day}$. Adequate phosphorus restriction is often difficult to achieve, without unduly restricting protein intake. Consequently, almost all PD patients require the use of phosphorus binders to prevent the development of hyperphosphatemia. The mean daily dose of whey powder consumed by the whey protein group was $26.3 \pm 3.1 \mathrm{~g} /$ day, which contains $91.8 \mathrm{mg}$ /day phosphorus. All participants continued their PD prescriptions, antihypertensive therapy, and other regular medications during the 12 -week study period. The higher serum phosphorus levels in the whey protein group may be related to the higher absorption rate and to the higher digestibility of whey protein; ${ }^{46}$ this was reflected by the higher nPNA and serum phosphorus levels in the whey protein group. Therefore, serum phosphorus levels should be monitored in PD patients who receive whey protein supplementation, and phosphorus-binder dosages should be adjusted accordingly, to prevent an increase in serum phosphorus levels.

As $100 \mathrm{~g}$ of whey powder contains $75 \mathrm{~g}$ whey protein, and since the mean daily dose of whey powder used in the whey protein group was $26.3 \pm 3.1 \mathrm{~g}$ /day, participants in the whey protein group received, in addition to their daily regular protein diet, about $19.7 \mathrm{~g}$ whey protein daily. Although, overall, the whey protein and control groups consumed comparable quantities of proteins, the increase in nPNA was lower in the control group than in the whey protein group. We presume that this is due to the composition of whey protein, including a higher content of essential amino acids, as well as to its high digestibility, and rapid absorption compared to the regular protein consumed by the control group participants. ${ }^{46}$ In addition, several studies, including a meta-analysis of nine randomized controlled trials, showed that whey protein has anti-inflammatory activities, increases synthesis of the antioxidant glutathione, and decreases plasma cytokine and CRP levels. ${ }^{47-54}$ Moreover, CRP levels in this context were found to be inversely correlated with nutritional markers. ${ }^{55}$ Congruent with these results, in the current study, plasma hsCRP levels decreased and nPNA increased among those who consumed the whey protein supplementation, but not among the patients in the control group. This suggests that by excreting favorable effects on systemic inflammation in hypoalbuminemic PD patients, whey protein improves nutritional status. The reason that such effects were not observed in the control group may be related to the differences in the composition, digestibility, and absorption rates between regular protein and whey protein. ${ }^{46}$

This is the first report of the beneficial effects of whey protein supplementation on oncotic pressure, hydration status, and blood pressure in PD patients with hypoalbuminemia. In light of these favorable effects, together with the lack of significant side effects, whey protein supplementation may be considered an additional dietary component in hypoalbuminemic PD patients. Future studies are needed to examine the effect of whey proteins on various hypertensive populations.

\section{Limitations}

The present study was carried out in one center and included a relatively small number of patients. Although the findings provide useful information that can contribute to the management of hypoalbuminemic PD patients, further studies are needed to verify whether such intervention can reduce the higher risk of mortality in this population.

\section{Conclusion}

Whey protein supplementation for 12 weeks decreased MAP in hypoalbuminemic PD patients. Whey protein supplementation may be considered as a dietary component in the management of this population.

\section{Acknowledgments}

We are grateful to Dr Majd Khayr, Mr Edgim Rabia, and Mrs Fadol Rawia, Peritoneal Dialysis Unit - Galilee Medical Center, Nahariya, Israel for their assistance in performing the study.

\section{Disclosure}

The authors report no conflicts of interest in this work.

\section{References}

1. Beddhu S, Kaysen GA, Yan G, et al; HEMO Study Group. Association of serum albumin and atherosclerosis in chronic hemodialysis patients. Am J Kidney Dis. 2002;40:721-727.

2. Cooper BA, Penne EL, Bartlett LH, Pollock CA. Protein malnutrition and hypoalbuminemia as predictors of vascular events and mortality in ESRD. Am J Kidney Dis. 2004;43:61-66.

3. Shah NR, Dumler F. Hypoalbuminaemia - a marker of cardiovascular disease in patients with chronic kidney disease stages II-IV. Int J Med Sci. 2008;5:366-370.

4. Mehrotra R, Duong U, Jiwakanon S, et al. Serum albumin as a predictor of mortality in peritoneal dialysis: comparisons with hemodialysis Am J Kidney Dis. 2011;58(3):418-428.

5. Vargas CM, Obisesan T, Gillum RF. Association of serum albumin concentration, serum ionized calcium concentration, and blood pressure in the Third National Health and Nutrition Examination Survey. J Clin Epidemiol. 1998;51:739-746. 
6. Høstmark AT, Tomten SE, Berg JE. Serum albumin and blood pressure: a population-based, cross-sectional study. J Hypertens. 2005;23: 725-730.

7. Hu H, Sparrow D, Weiss S. Association of serum albumin with blood pressure in the normative aging study. Am J Epidemiol. 1992;136(12): 1465-1473.

8. Ando D, Hirawa N, Yasuda G. Relation between circadian blood pressure rhythm and serum albumin level in non-diabetic patients with proteinuria. Blood Press. 2016;25:44-50.

9. K/DOQI, National Kidney Foundation. Clinical practice guidelines for nutrition in chronic renal failure. Am J Kidney Dis. 2000;35(6 Suppl 2): S1-S140.

10. Dombros N, Dratwa M, Feriani M, et al; EBPG Expert Group on Peritoneal Dialysis. European best practice guidelines for peritoneal dialysis. 2 The initiation of dialysis. Nephrol Dial Transplant. 2005;20(Suppl 9): ix3-ix 7.

11. Lim VS, Flanigan MJ. Protein intake in patients with renal failure: comments on the current NKF-DOQI guidelines for nutrition in chronic renal failure. Semin Dial. 2001;14:150-152.

12. Hylander B, Barkeling B, Rössner S. Eating behavior in continuous ambulatory peritoneal dialysis and hemodialysis patients. Am J Kidney Dis. 1992;20(6):592-597.

13. Kopple JD. Therapeutic approaches to malnutrition in chronic dialysis patients: the different modalities of nutritional support. Am J Kidney Dis. 1999;33(1):180-185.

14. Kopple JD. National Kidney Foundation K/DOQI Work Group. The National Kidney Foundation K/DOQI clinical practice guidelines for dietary protein intake for chronic dialysis patients. Am J Kidney Dis. 2001;38(4 Suppl 1):S68-S73.

15. Marshall K. Therapeutic applications of whey protein. Altern Med Rev. 2004;9:136-156.

16. Sousa GT, Lira FS, Rosa JC, et al. Dietary whey protein lessens several risk factors for metabolic diseases: a review. Lipids Health Dis. 2012; 11:67.

17. Katsanos CS, Chinkes DL, Paddon-Jones D, Zhang XJ, Aarsland A, Wolfe RR. Whey protein ingestion in elderly persons results in greater muscle protein accrual than ingestion of its constituent essential amino acid content. Nutr Res. 2008;28:651-658.

18. Madureira AR, Tavares T, Gomes AM, Pintado ME, Malcata FX. Invited review: physiological properties of bioactive peptides obtained from whey proteins. J Dairy Sci. 2010;93(2):437-455.

19. Abbott RD, Curb JD, Rodriguez BL, Sharp DS, Burchfiel CM, Yano K. Effect of dietary calcium and milk consumption on risk of thromboembolic stroke in older middle-aged men. The Honolulu Heart Program. Stroke. 1996;27:813-818.

20. Parodi PW. A role for milk proteins and their peptides in cancer prevention. Curr Pharm Des. 2007;13(8):813-828.

21. Yalçin AS. Emerging therapeutic potential of whey proteins and peptides. Curr Pharm Des. 2006;12(13):1637-1643.

22. Zemel MB. The role of dairy foods in weight management. J Am Coll Nutr. 2005;24(6 Suppl):537S-546S.

23. Hakkak R, Korourian S, Ronis MJ, Johnston JM, Badger TM. Dietary whey protein protects against azoxymethane-induced colon tumors in male rats. Cancer Epidemiol. 2001;10(5):555-558.

24. Xiao R, Carter JA, Linz AL, Ferguson M, Badger TM, Simmen FA. Dietary whey protein lowers serum C-peptide concentration and duodenal SREBP-1c mRNA abundance, and reduces occurrence of duodenal tumors and colon aberrant crypt foci in azoxymethane-treated male rats. J Nutr Biochem. 2006;17(9):626-634.

25. Graf S, Egert S, Heer M. Effects of whey protein supplements on metabolism: evidence from human intervention studies. Curr Opin Clin Nutr Metab Care. 2011;14(6):569-580.

26. Krissansen GW. Emerging health properties of whey proteins and their clinical implications. J Am Coll Nutr. 2007;26(6):713S-723S.

27. Sundell J, Hulmi J, Rossi J. Whey protein and creatine as nutritional supplements. Duodecim. 2011;127(7):700-705.

28. Wal JM. Bovine milk allergenicity. Ann Allergy Asthma Immunol. 2004; 93(5 Suppl 3):S2-S11.
29. Saito T. Antihypertensive peptides derived from bovine casein and whey proteins. Adv Exp Med Biol. 2008;606:295-317.

30. FitzGerald RJ, Meisel H. Lactokinins: whey protein-derived ACE inhibitory peptides. Nahrung. 1999;43:165-167.

31. Mullaly M, Meisel H, FitzGerald R. Angiotensin-I-converting enzyme inhibitory activities of gastric and pancreatic proteinase digest of whey proteins. Int Dairy. 1997; 7:299-303.

32. FitzGerald RJ, Meisel H. Milk protein-derived peptide inhibitors of angiotensin-I-converting enzyme. Br J Nutr. 2000;84(Suppl 1): S33-S37.

33. Abubakar A, Tadao S, Kitazawa H, Kawai Y, Itoh T. Structural analysis of new antihypertensive peptides derived from cheese whey protein by proteinase K digestion. J Dairy Sci. 1998;81:3131-3138.

34. Hur E, Gungor O, Musayev O, et al. Bioimpedance spectroscopy for the detection of hypervolemia in peritoneal dialysis patients. Adv Perit Dial. 2011;27:65-70

35. Bergström J, Heimbürger O, Lindholm B. Calculation of the protein equivalent of total nitrogen appearance from urea appearance. Which formulas should be used? Perit Dial Int. 1998;18(5):467-473.

36. Appel LJ, Brands MW, Daniels SR, Karanja N, Elmer PJ, Sacks FM. American Heart Association. Dietary approaches to prevent and treat hypertension: a scientific statement from the American Heart Association. Hypertension. 2006;47:296-308.

37. Pal S, Ellis V. The chronic effects of whey proteins on blood pressure, vascular function, and inflammatory markers in overweight individuals. Obesity. 2010;18:1354-1359.

38. Lee YM, Skurk T, Hennig M, Hauner H. Effect of a milk drink supplemented with whey peptides on blood pressure in patients with mild hypertension. Eur J Nutr. 2007;46:21-27.

39. Yamamoto N, Takano T. Antihypertensive peptides derived from milk proteins. Nahrung. 1999;43:159-164.

40. Seppo L, Jauhiainen T, Poussa T, Korpela R. A fermented milk high in bioactive peptides has a blood pressure-lowering effect in hypertensive subjects. Am J Clin Nutr. 2003;77:326-330.

41. Kawase M, Hashimoto H, Hosoda M, Morita H, Hosono A. Effect of administration of fermented milk containing whey protein concentrate to rats and healthy men on serum lipids and blood pressure. J Dairy Sci. 2000;83:255-263.

42. Takano T. Milk derived peptides and hypertension reduction. Int Dairy J. 1998;8:375-381.

43. Nurminen ML, Sipola M, Kaarto H, et al. Alpha-lactorphin lowers blood pressure measured by radiotelemetry in normotensive and spontaneously hypertensive rats. Life Sci. 2000;66:1535-1543.

44. Sekiya S, Kobayashi Y, Kita E, Imamura Y, Toyama S. Antihypertensive effects of tryptic hydrolysate of casein on normotensive and hypertensive volunteers (in Japanese). J Jpn Soc Nutr Food Sci. 1992;45: 513-517.

45. Hata Y, Yamamoto M, Ohni M, Nakajima K, Nakamura Y, Takano TA. placebo-controlled study of the effect of sour milk on blood pressure in hypertensive subjects. Am J Clin Nutr. 1996;64(5):767-771.

46. Sousa GT, Lira FS, Rosa JC, et al. Dietary whey protein lessens several risk factors for metabolic diseases: a review. Lipids Health Dis. 2012; 11:67.

47. Marshall K. Therapeutic applications of whey protein. Altern Med Rev. 2004;9:136-156.

48. Pal S, Ellis V. The chronic effects of whey proteins on blood pressure, vascular function, and inflammatory markers in overweight individuals. Obesity (Silver Spring). 2010;18(7):1354-1359.

49. Zhou LM, Xu JY, Rao CP, Han S, Wan Z, Qin LQ. Effect of whey supplementation on circulating C-reactive protein: a meta-analysis of randomized controlled trials. Nutrients. 2015;7:1131-1141.

50. Petyaev IM, Dovgalevsky PY, Klochkov VA, Chalyk NE, Kyle N. Whey protein lycosome formulation improves vascular functions and plasma lipids with reduction of markers of inflammation and oxidative stress in prehypertension. Sci World J. 2012;2012:269476.

51. Sugawara K, Takahashi H, Kashiwagura T, et al. Effect of antiinflammatory supplementation with whey peptide and exercise therapy in patients with COPD. Respir Med. 2012;106:1526-1534. 
52. Bharadwaj S, Naidu TAG, Betageri GV, Prasadarao NV, Naidu AS. Inflammatory responses improve with milk ribonuclease-enriched lactoferrin supplementation in postmenopausal women. Inflamm Res. 2010;59:971-978.

53. Kerasioti E, Stagos D, Jamurtas A, et al. Anti-inflammatory effects of a special carbohydrate-whey protein cake after exhaustive cycling in humans. Food Chem Technol. 2013;61:42-46.
54. Tomayko EJ, Kistler BM, Fitschen PJ, Wilund KR. Intradialytic protein supplementation reduces inflammation and improves physical function in maintenance hemodialysis patients. J Ren Nutr. 2015;25(3): 276-283.

55. Fein PA, Mittman N, Gadh R, et al. Malnutrition and inflammation in peritoneal dialysis patients. Kidney Int Suppl. 2003; Nov (87):S87-S91.

\section{Publish your work in this journal}

Therapeutics and Clinical Risk Management is an international, peerreviewed journal of clinical therapeutics and risk management, focusing on concise rapid reporting of clinical studies in all therapeutic areas, outcomes, safety, and programs for the effective, safe, and sustained use of medicines. This journal is indexed on PubMed Central, CAS,
EMBase, Scopus and the Elsevier Bibliographic databases. The manuscript management system is completely online and includes a very quick and fair peer-review system, which is all easy to use. Visit http://www.dovepress.com/testimonials.php to read real quotes from published authors.

Submit your manuscript here: http://www.dovepress.com/therapeutics-and-clinical-risk-management-journal 